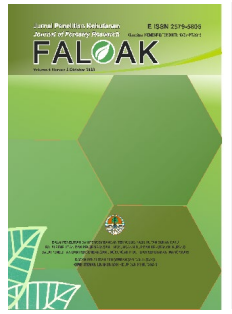

Jurnal Penelitian Kehutanan Faloak (2021) 5(2), 132-143

JURNAL PENELITIAN KEHUTANAN FALOAK

Akreditasi KEMENRISTEKDIKTI: 10/E/KPT/2019

http://ejournal.forda-mof.org/ejournal-litbang/index.php/JPKF

\title{
PENGARUH MODIFIKASI TINGGI SOK PENYULINGAN DAN JENIS BUNGA LONTAR (Borassus flabellifer L.) TERHADAP KUALITAS PRODUK SOPI TIMOR (The effect of refineries elevation and palm (Borassus flabelliferL.) flower types on the quality of Timor Sopi Products)
}

\author{
Syprianus Ceunfin ${ }^{1}$, Yakobus P. E. S. Agu ${ }^{2}$ dan Martinus Reno Manikin ${ }^{3^{*}}$ \\ ${ }^{1}$ Universitas Timor, Jln. Eltari Km.9, Sasi, Kefamenanu, 85613.
}

${ }^{2}$ Program Studi Agroteknologi, Fakultas Pertanian, Universitas Timor Jln. Eltari Km.9, Sasi, Kefamenanu, NTT, 85613

\begin{abstract}
Lontar (Borassus flabellifer L.)is a featured product of Timor Island that can be used for variuos purposes, including traditional drink. The improvement on the quality of distilled traditional drink is required to increase economic value and also community income in the same time through distillery system modification. The aim of this study was to find the influence of modified distillery (sok height) and flower type of sap on the traditional drink quality. The study was conducted using a fully randomized factorial design of four sok height variables (50, 100, 150, and $200 \mathrm{~cm})$ and flower types sap variables (female, male, and mixed). Analysis of varian was used to determine variables and drink qualities relationship. The results showed that there was no interaction between sok height and flower type sap. The combination of variables (sok heightand flower type sap) influenced the traditional drink quality, including alcohol content, $p H$, total dissolved solids, color, flavor, and taste of the drink. A good alcohol content was resulted from the combination of a 200 $\mathrm{cm}$ sok high and mixed flower sap. The great pH of drink was obtained from male flower sap. The total dissolved solids, color, flavor, and taste were in the range of drinks requierment. The research results imply that for the distillation of traditional drink, a $200 \mathrm{~cm}$ high and mixed Lontar flowersap could be used to obtain a good quality of traditional drink product.
\end{abstract}

Keywords: Lontar, sok height, sopi, flower type sap, distillery system modification

\begin{abstract}
ABSTRAK
Lontar (Borassus flabelliferL.) merupakan produk unggulan dari Pulau Timor yang banyak digunakan untuk berbagai keperluan, salah satunya adalah minuman tradisional (sopi). Peningkatan kualitas hasil penyulingan lontar diperlukan untuk meningkatkan nilai ekonomi produk dan pendapatan masyarakat melalui modifikasi sistem penyulingan. Penelitian ini bertujuan untuk mengetahui pengaruh tinggi sok dan jenis bunga nira terhadap kualitas minuman tradisional. Penelitian ini menggunakan rancangan acak lengkap faktorial yang terdiri atas faktor tinggi sok (50, 100, 150 dan 200 $\mathrm{cm}$ ) dan jenis nira bunga lontar terdiri (betina, jantan dan campuran). Hasil penelitian menunjukan bahwa tidak terjadi interaksi antar perlakuan, tetapi terjadi beda nyata antar perlakuan tinggi sok dan jenis nira bunga lontar terhadap kadar alkohol, pH alkohol, total padatan terlarut, warna, aroma serta rasa sopi. Kadar alkohol sopi yang baik dihasilkan dari perlakuan tinggi sok $200 \mathrm{~cm}$ dan jenis nira campuran. $\mathrm{pH}$ yang baik didapatkan dari jenis nira bunga jantan. Total padatan terlarut, warna, aroma, dan rasa berada dalam batas yang diperkenankan. Implikasi dari hasil penelitian adalah untuk mendapatkan produk minuman tradisional dengan kualitas yang baik, maka sistem penyulingan menggunakan tinggi sok $200 \mathrm{~cm}$ dan jenis bunga lontar campuran.
\end{abstract}

Kata kunci: Lontar, tinggi sok, sopi, jenis bunga lontar, modifikasi sistem penyulingan.

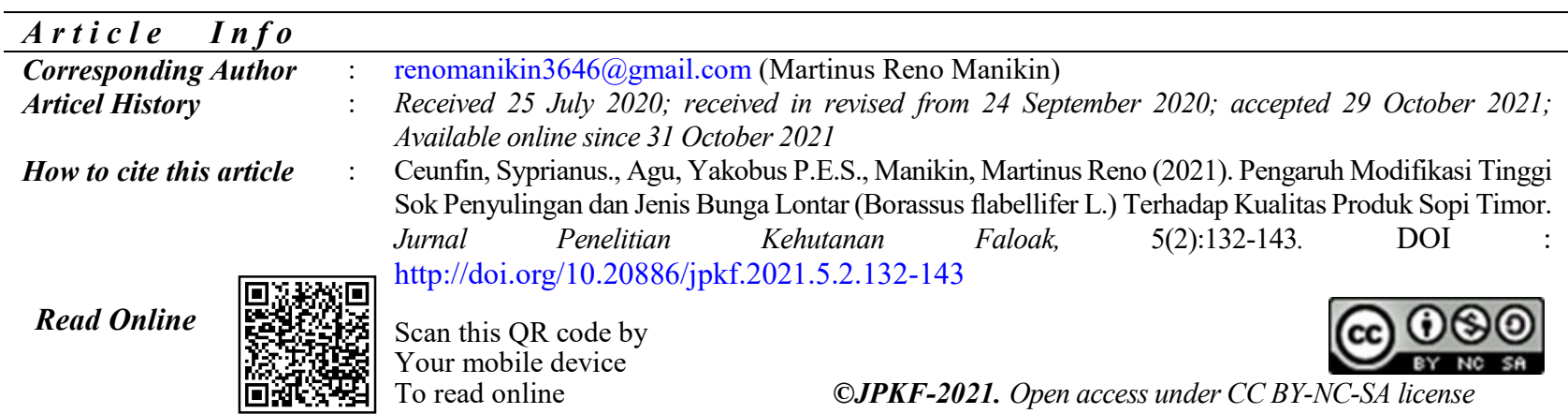




\section{PENDAHULUAN}

Indonesia merupakan salah satu negara yang memiliki keanekaragaman hayati terbesar didunia, sehingga bisa dijadikan modal dasar dalam pembangunan, termasuk di bidang industri. Sumber daya alam yang dimiliki harus dapat dimanfaatkan untuk meningkatkan kesejahteraan masyarakat (Kristanto, 2011). Salah satu sumberdaya alam yang mempunyai potensi untuk dikembangkan adalah tumbuhan lontar (Borassus flabellifer L.) (Parlindungan, 2010; Li, 2013). Pulau Timor, Provinsi Nusa Tenggara Timur (NTT) merupakan salah satu wilayah persebaran lontar (Rahmansyah, 2001).

Lontar merupakan tumbuhan serbaguna yang menghasilkan produk yang dapat dijadikan unggulan daerah dan nasional. Seluruh bagian tumbuhan lontar dapat dimanfaatkan oleh masyarakat dan bernilai ekonomi (Subrimobdi, 2016; Detha \& Datta, 2016b). Salah satu bagian penting dari lontar yang dapat dimanfaatkan adalah nira. Nira merupakan cairan yang disadap dari bunga jantan dan bunga betina pohon lontar. Nira memiliki kandungan gula sekitar $10-15 \%$ dalam bentuk sukrosa, fruktosa, dan glukosa, serta karbohidrat dengan derajat keasaman netral yaitu 6-7. Jika nira disimpan dalam waktu yang lama akan terjadi proses fermentasi oleh mikroorganisme sehingga akan menyebabkan perubahan rasa menjadi asam (Lempang, 2007; Detha \& Datta, 2016a; Mardiyah, 2017). Nira bunga lontar telah lama dimanfaatkan oleh masyarakat di wilayah NTT sebagai bahan dasar pembuatan minuman tradisional sopi (Detha \& Datta, 2015). Hasil dari produk lontar berupa sopi memiliki banyak kegunaan dalam berbagai upacara adat, seperti pernikahan. Nira juga dapat diolah menjadi minuman ringan lainnya, seperti sirup lontar, gula dan nata de tala (Lempang, 2007). Aktivitas pengolahan nira menjadi bagian sumber pendapatan pada masyarakat pedesaan di Pulau Timor (Nurtama \& Naomi, 2010; Rena,
2012; Datta \& Detha, 2016).

Proses pembuatan sopi, diawali dengan penyadapan nira dari pohon lontar yang selanjutnya nira dimasak dalam wadah penyulingan (periuk tanah). Proses pemanasan dilakukan dengan kondisi api menyala sampai pada titik didih. Nira yang dipanaskan hingga titik didih ini akan menghasilkan sopi dari proses penyulingan. Proses penyulingan dilakukan dengan mengalirkan uap nira melalui bambu penyulingan (Mantut et al., 2019). Kualitas sopi pada umumnya berbeda tergantung proses penyulingannya (Surroya, 2016). Kualitas sopi sangat dipengaruhi oleh media penyulingan (sok) yang digunakan. Masyarakat pada umumnya menggunakan sok penyulingan dengan tinggi $50-100 \mathrm{~cm}$, akan tetapi sopi yang dihasilkan memiliki kualitas yang kurang baik (Naiola, 2008; BPOM, 2014). Hasil penelitian Wenur \& Waromi (2017) menyebutkan bahwa media penyulingan berpengaruh terhadap hasil yang diperoleh. Media penyulingan dengan menggunakan drum bekas menghasilkan kadar alkohol sebesar 24\% dengan bahan baku nira aren. Penelitian yang dilakukan oleh Manus (2017) diperoleh hasil kadar alkohol sopi sebesar 37,67\% tanpa fermentasi dengan wadah penyulingan periuk tanah. Kadar alkohol, rasa dan aroma hasil penyulingan juga dipengaruhi oleh tinggi sok dan jenis bunga lontar yang digunakan. Oleh sebab itu perlu dilakukan penelitian pengaruh media penyulingan (tinggi sok) terhadap kualitas produk sopi dan kualitas produk sopi berdasarkan jenis nira bunga Lontar (Rahman, 2007; Hidayanti, 2012).

Penelitian ini bertujuan untuk mengetahui pengaruh modifikasi media penyulingan (tinggi sok) dan penggunaan nira bunga lontar (jantan, betina) terhadap kualitas produk sopi. Hipotesis yang digunakan pada penelitian ini adalah perbedaan tinggi sok atau media penyulingan dan jenis nira bunga lontar 
akan memengaruhi kualitas produk sopi yang dihasilkan. Hasil penelitian ini diharapkan dapat memberikan tambahan wawasan keilmuan mengenai pengaruh teknik penyulingan dan asal nira terhadap produk sopi serta sebagai bahan informasi kepada masyarakat dalam rangka peningkatan kualitas produk sopi yang dihasilkan.

\section{METODE PENELITIAN}

Penelitian ini dilaksanakan di Desa
Letmafo pada tahun 2019. Secara administratif Desa Letmafo berada di Kecamatan Insana Tengah, Kabupaten Timor Tengah Utara, Provinsi Nusa Tenggara Timur (Gambar 1). Keadaan topografi desa Letmafo pada umumnya didominasi oleh kemiringan lereng $15 \%$ dengan ketinggian tempat $500 \mathrm{mdpl}$. Sebagian besar penduduk desa Letmafo memiliki profesi sebagai petani dan produsen sopi dari nira lontar.

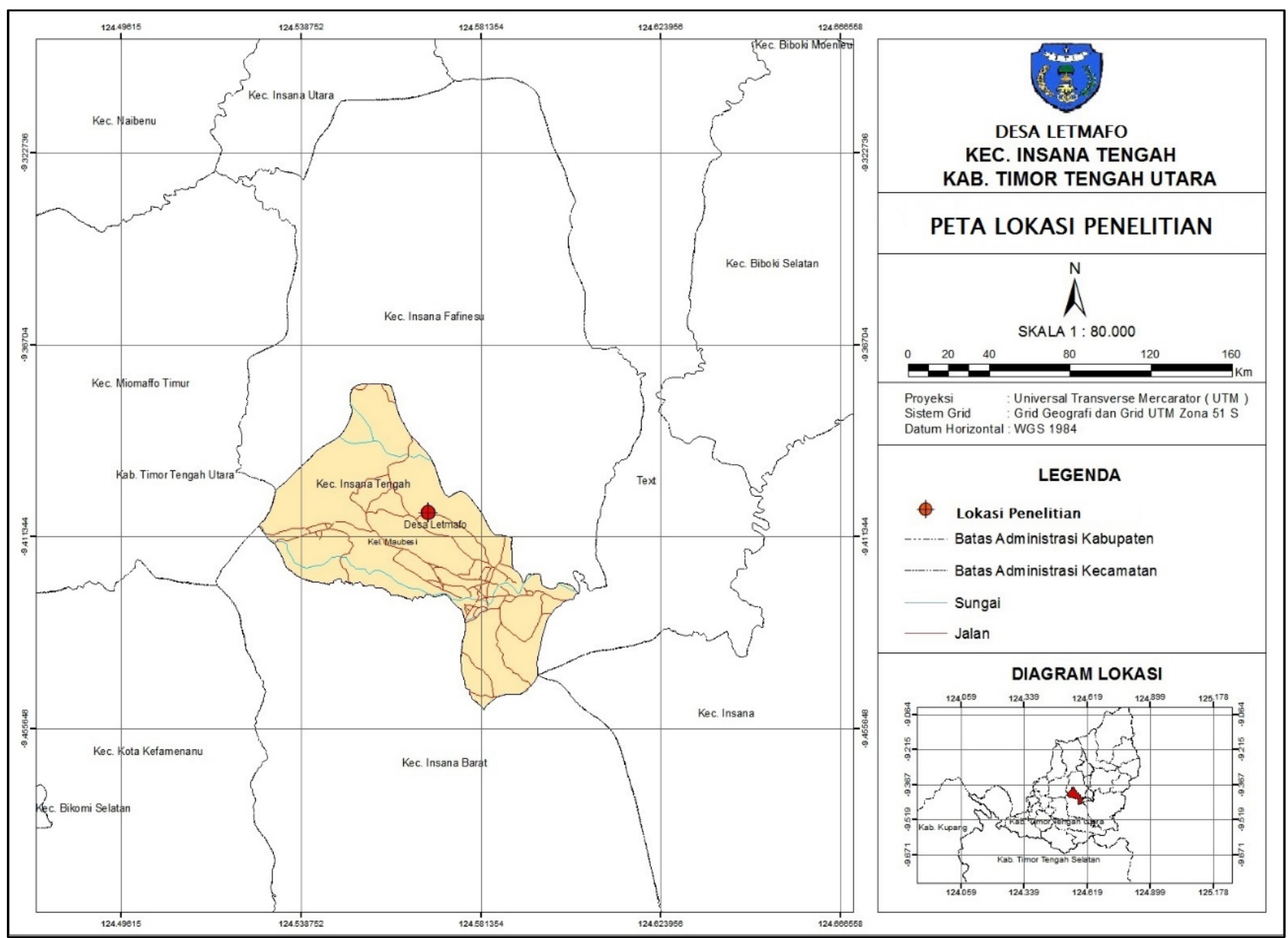

Gambar 1. Peta lokasi Desa Letmafo, Kecamatan Insana Tengah, Kabupaten Timor Tengah Utara, Provinsi Nusa Tenggara Timur.

Figure 1. Map of Lemafo Village, Insana Tengah Subdistrick, Timor Tengah Utara District, East Nusa Tenggara province 
Pemilihan pohon lontar sebagai sampel pengambilan nira dipilih pohon yang banyak digunakan oleh masyarakat. Pohon sampel yang dipilih sebanyak 30 pohon yang terdiri atas 15 pohon lontar betina dan 15 pohon lonta jantan. Media penyulingan yang digunakan adalah bambu. Bambu dibersihkan bukubukunya hingga bersih dan dipotong sesuai dengan ukuran masing-masing perlakuan. Sok dibersihkan menggunakan pipa dengan menyisakan satu buku dibagian atas dan dilubangi menggunakan pahat sesuai dengan ukuran bambu penyulingan. Bambu penyulingan diikat dengan masing-masing ukuran sok dan dipasang pada masing-masing wadah penyulingan dengan kemiringan bambu sesuai ukuran sok penyambung. Penyulingan dilakukan menggunakan nira lontar yang disadap dari pohon tanpa difermentasikan. Setiap satuan unit percobaan menggunakan nira lontar sebanyak 15 liter. Penyulingan dilakukan dengan cara membuat api, sekaligus wadah penyulingan ditempatkan diatas tungku penyulingan.

Rancangan penelitian yang digunakan dalam penelitian ini adalah eksperimen menggunakan Rancangan Acak Lengkap (RAL) pola faktorial, yang terdiri atas 2 faktor. Faktor pertama adalah tinggi sok (S) yang terdiri atas: tinggi sok $50 \mathrm{~cm}(\mathrm{~S} 1)$, tinggi sok $100 \mathrm{~cm}(\mathrm{~S} 2)$, tinggi sok $150 \mathrm{~cm}(\mathrm{~S} 3)$ dan tinggi sok $200 \mathrm{~cm}$ (S4). Faktor kedua adalah jenis nira lontar (N) yang digunakan dan terdiri atas : nira lontar dari pohon betina (N1), nira lontar dari pohon jantan (N2), dan kombinasi nira lontar jantan dan nira lontar betina (N3). Dengan demikian terdapat 12 satuan unit percobaan dan masingmasing perlakuan diulang sebanyak 3 kali sehingga terdapat 36 unit percobaan. Kombinasi perlakuan terdiri dari N1S1, N1S2, N1S3, N1S4, N2S1, N2S2, N2S3, N2S4, N3S1, N3S2, N3S3,
N3S4.

Variabel pangamatan pada penelitian ini adalah kadar alkohol, $\mathrm{pH}$, total padatan terlarut, warna, aroma dan rasa. Pengukuran kadar alkohol pada penelitian menggunakan metode Guymon, sedangkan pengukuran $\mathrm{pH}$ menggunakan $\mathrm{pH}$ meter. Pengujian total padatan terlarut dilakukan dengan menggunakan hand-refractometer. Pengujian organoleptik dilakukan untuk variabel warna, aroma dan rasa. Pemeriksaan dan penilaian dilakukan dengan menggunakan panca indera, dan metode yang banyak digunakan pada saat uji ini adalah indera penglihatan, indera pembau, indera peraba, dan indera pengecap. Pengujian parameter organoleptik dilakukan oleh responden yaitu masyarakat atau petani lontar di Desa Letmafo. Pengujian parameter warna pada suatu produk merupakan parameter utama bagi kenampakan produk secara keseluruhan. Sampel sopi dituangkan kedalam gelas berukuran kecil transparan lalu diamati warnanya dengan indra penglihatan/mata. Sementara itu nilai organoleptik aroma di uji dengan cara responden mencium aroma produk sopi lalu memberi nilai secara kualitatif dan kuantitatif. Pemberian nilai pada organoleptik aroma dibagi ke dalam lima kelas, yaitu sangat tidak suka (0-20), tidak suka (20-40), netral (40$60)$, suka (60-80) dan sangat suka (80-100). Nilai organoleptik rasa di uji dengan cara responden mencicipi produk sopi dengan indera pengecap dan selanjutnya memberikan penilaian kualitatif dan kuantitatif, yaitu sangat tidak suka (0-20), tidak suka (20-40), netral (4060), suka (60-80) dan sangat suka (80-100). Analisis statistik yaitu analisis varian digunakan untuk mengetahui pengaruh perlakuan berdasarkan variabel kualitas sofi hasil penyulingan. 


\section{HASIL DAN PEMBAHASAN}

\section{A. Kadar Alkohol (\%)}

Etil alkohol $\left(\mathrm{CH}_{3} \mathrm{CH}_{2} \mathrm{OH}\right)$ yang juga dikenal dengan nama alkohol merupakan cairan yang mempunyai sifat fisik berbentuk cair, mudah menguap, dapat bercampur dengan air dalam segala perbandingan, mendidih pada suhu $79^{\circ} \mathrm{C}$, membeku pada suhu $117^{\circ} \mathrm{C}$ dan mempunyai berat $46 \mathrm{~g} / \mathrm{mol}$ (Arintawati, 2006; Hotmaka dan Ebner, 1995). Sopi mengandung alkohol yakni etanol $\left(\mathrm{CH}_{3} \mathrm{CH}_{2} \mathrm{OH}\right)$ dari fermentasi nira yang telah mengalami destilasi (Detha dan Datta, 2016c; Aryasa et al., 2020; Wael S, 2013). Hasil sidik ragam (Tabel 1) menunjukkan bahwa tidak terjadi interaksi antara perlakuan jenis nira bunga Lontar dan perlakuan tinggi sok terhadap kadar alkohol sopi. Perlakuan jenis nira campuran antara nira dari bunga jantan dan nira dari bunga betina menghasilkan kandungan alkohol paling tinggi
(36,51\%). Hal ini berbeda sangat nyata dengan nira dari bunga jantan, tetapi tidak berbeda nyata dengan perlakuan jenis nira bunga betina. Sedangkan pada perlakuan tinggi sok, tinggi sok $200 \mathrm{~cm}$ menghasilkan sopi dengan kandungan alkohol paling tinggi yaitu $38,55 \%$ yang berbeda sangat nyata dengan tinggi sok $50 \mathrm{~cm}$ dan tinggi sok $100 \mathrm{~cm}$, namun tidak berbeda nyata dengan perlakuan sok $150 \mathrm{~cm}$.

Sopi yang baik adalah sopi yang termasuk dalam minuman alkohol golongan $\mathrm{c}$ yaitu memiliki kandungan alkohol dibawah 55\%. Berdasarkan hasil penelitian, kombinasi terbaik antara antara tinggi sok pada jenis bunga lontar yang menghasilkan produk sopi dengan kandungan alkohol yang paling baik yaitu tinggi sok $200 \mathrm{~cm}$ pada jenis bunga lontar campuran antara bunga lontar jantan dan bunga lontar betina. Pada kombinasi ini menghasilkan sopi dengan kadar alkohol sebesar 38,55\%.

Tabel 1. Pengaruh Modifikasi Media Penyulingan dan Jenis Bunga Lontar Terhadap Kadar Alkohol

Table 1. The effect of modification of distillation media and palm flower type on alcohol content

\begin{tabular}{|c|c|c|c|c|c|}
\hline \multirow{2}{*}{$\begin{array}{c}\begin{array}{c}\text { Perlakuan } \\
\text { (treatment) }\end{array} \\
\text { Jenis Nira } \\
\text { (roomie type) }\end{array}$} & \multicolumn{4}{|c|}{$\begin{array}{l}\text { Tinggi sok penyulingan (cm) } \\
\text { (High refining shock) }\end{array}$} & \multirow{2}{*}{$\begin{array}{c}\text { Rerata } \\
\text { (average) }\end{array}$} \\
\hline & 50 (S1) & 100 (S2) & 150 (S3) & 200 (S4) & \\
\hline Betina (N1) & 31,00 & 32,66 & 36,66 & 40,00 & $35,08^{a b}$ \\
\hline Jantan (N2) & 31,66 & 32,00 & 38,00 & 35,26 & $34,23^{b}$ \\
\hline Campuran (N3) & 31,66 & 35,66 & 38,33 & 40,40 & $36,51^{\mathrm{a}}$ \\
\hline Rerata & $31,44^{b}$ & $33,44^{b}$ & $37,66^{\mathrm{a}}$ & $38,55^{\mathrm{a}}$ & \\
\hline
\end{tabular}

Keterangan (Remark): angka yang diikuti huruf sama menunjukan tidak berbeda nyata pada $\alpha=5 \%$ (mean value followed by same letter indicated not significantly different at $\alpha=5 \%$ ) 


\section{B. Nilai pH}

Nilai $\mathrm{pH}$ adalah derajat keasaman yang digunakan untuk menyatakan tingkat keasaman atau kebasahan yang dimiliki oleh suatu larutan. Nilai $\mathrm{pH}$ yang baik untuk standar produk sopi yaitu dengan kodisi $\mathrm{pH}$ netral yaitu dengan kisaran 6-7. Hasil penelitian menunjukkan bahwa antara perlakuan jenis nira bunga lontar dan tinggi sok tidak memberikan pengaruh yang signifikan terhadap $\mathrm{pH}$ sopi. Pada perlakuan jenis nira bunga jantan memiliki rata nilai $\mathrm{pH}$ tertinggi untuk semua kombinasi tinggi sok yaitu 3,89 , yang sangat berbeda nyata dengan nira dari bunga betina serta campuran.
Perlakuan tinggi sok berdasarkan hasil sidik ragam (anova) tidak berbeda nyata untuk semua asal nira. Hasil $\mathrm{pH}$ tersebut juga masih jauh dari netral (Tabel 2). Oleh karena itu perlu peningkatan mutu $\mathrm{pH}$ alkohol agar dapat menyerupai $\mathrm{pH}$ pada bioetanol. Proses destilasi merupakan proses penting dalam menghasilkan mutu bioetanol yang baik. Destilasi akan memisahkan etanol dengan komponenkomponen yang lain sehingga komponen yang bersifat asam akan hilang. Hal ini sesuai dengan pendapat Richana (2011) bahwa standar mutu kualitas bioetanol sebagai bahan bakar salah satunya adalah memiliki pH 6,5.

Tabel 2. Pengaruh Modifikasi Media Penyulingan dan Jenis Bunga Lontar Terhadap pH Table 2. The effect of modification of distillation media and palm flower type on $\mathrm{pH}$

\begin{tabular}{|c|c|c|c|c|c|}
\hline \multirow{2}{*}{$\begin{array}{c}\begin{array}{c}\text { Perlakuan } \\
\text { (treatment) }\end{array} \\
\begin{array}{c}\text { Jenis Nira } \\
\text { (roomie type) }\end{array}\end{array}$} & \multicolumn{4}{|c|}{$\begin{array}{c}\text { Tinggi sok penyulingan (cm) } \\
\text { (high refining shock) }\end{array}$} & \multirow{2}{*}{$\begin{array}{r}\text { Rata-rata } \\
\text { (average) }\end{array}$} \\
\hline & $50(\mathrm{~S} 1)$ & $100(\mathrm{~S} 2)$ & $150(\mathrm{S3})$ & $200(\mathrm{~S} 4)$ & \\
\hline Betina (N1) & 3,46 & 3,8 & 3,5 & 3,83 & $3,65^{b}$ \\
\hline Jantan (N2) & 4,00 & 3,66 & 4,23 & 3,66 & $3,89^{\mathrm{a}}$ \\
\hline Campuran (N3) & 3,23 & 3,33 & 3,23 & 3,07 & $3,21^{\mathrm{c}}$ \\
\hline Rata-rata & $3,56^{\mathrm{a}}$ & $3,60^{\mathrm{a}}$ & $3,65^{\mathrm{a}}$ & $3,52^{a}$ & \\
\hline
\end{tabular}

Keterangan (Remark): angka yang diikuti huruf sama menunjukan tidak berbeda nyata pada $\alpha=5 \%$ (mean value followed by same letter indicated not significantly different at $\alpha=5 \%$ )

Di sisi lain, pangan olahan yang mengandung alkohol belum ada standarisasi $\mathrm{pH}$ dari BPOM ataupun Kementrian Kesehatan Indonesia, namun pada $\mathrm{pH}$ bioetanol sudah ada standarisasi mutu $\mathrm{pH}$ yaitu 6,5. Oleh karena itu perlu adanya standarisasi $\mathrm{pH}$ dalam pangan olahan yang mengandung alkohol.

\section{Total Padatan Terlarut}

Berdasarkan hasil analisis varian (Tabel 3), diperoleh bahwa tidak terjadi interaksi antar perlakuan. Total padatan terlarut yang terkandung dalam hasil produk sopi antara perlakuan jenis nira memberikan hasil yang berbeda nyata yaitu jenis nira campuran memiliki hasil 17,49\% yang sangat berbeda nyata dengan jenis nira bunga jantan, tetapi tidak berbeda nyata dengan perlakuan jenis nira bunga betina. Sedangkan pada perlakuan tinggi sok penyulingan hasil total padatan terlarut paling tinggi pada sok $200 \mathrm{~cm}$ yang berbeda nyata dengan perlakuan sok $50 \mathrm{~cm}$. 
Tabel 3. Pengaruh Modifikasi Media Penyulingan dan Jenis Bunga Lontar Terhadap Total Padatan Terlarut

Table 3. The effect of modification of distillation media and palm flower type on total dissolved solids

\begin{tabular}{|c|c|c|c|c|c|}
\hline \multirow{2}{*}{$\begin{array}{c}\begin{array}{c}\text { Perlakuan } \\
\text { (treatment) }\end{array} \\
\text { Jenis Nira } \\
\text { (roomie type) }\end{array}$} & \multicolumn{4}{|c|}{$\begin{array}{l}\text { Tinggi sok penyulingan (cm) } \\
\text { (high refining shock) }\end{array}$} & \multirow{2}{*}{$\begin{array}{l}\text { Rata-rata } \\
\text { (average) }\end{array}$} \\
\hline & 50 (S1) & 100 (S2) & 150 (S3) & 200 (S4) & \\
\hline Betina (N1) & 13,66 & 15,33 & 16,66 & 18,66 & $16,08 \mathrm{a}$ \\
\hline Jantan (N2) & 13,66 & 12,33 & 14,66 & 13,33 & $13,50 \mathrm{~b}$ \\
\hline Campuran (N3) & 14,00 & 17,00 & 19,00 & 19,98 & 17,49 a \\
\hline Rata-rata & $13,77 \mathrm{c}$ & $14,88 \mathrm{bc}$ & $16,77 \mathrm{ab}$ & $17,32 \mathrm{a}$ & \\
\hline
\end{tabular}

Keterangan (Remark): angka yang diikuti huruf sama menunjukan tidak berbeda nyata pada $\alpha=5 \%$ (mean value followed by same letter indicated not significantly different at $\alpha=5 \%$ )

Berdasarkan hasil penelitian, kombinasi antara tinggi sok dan jenis bunga lontar yang menghasilkan kualitas sopi dengan total padatan terlarut terkecil yaitu kombinasi antara tinggi sok $150 \mathrm{~cm}$ dengan jenis nira bunga jantan. Total padatan terlarut adalah bahan-bahan terlarut dengan diameter $<10-6 \mathrm{~mm}$ dan koloid yang berupa senyawa kimia ataupun bahanbahan lain yang tidak tersaring oleh kertas saring dengan diameter $0.45 \mu \mathrm{m}$. Total padatan terlarut juga merupakan jumlah material terlarut air dalam suatu bahan meliputi total gula, asam organik, pektin dan protein. Standarisasi total padatan terlarut pada minuman beralkohol belum ada sehingga pada penelitian ini menggunakan fermentasi pada kefir susu (Asosiasi Kefir Susu Indonesia, 2016). Total padatan terlarut hasil penelitian menunjukkan masih berada di bawah ambang batas, sehingga masih aman untuk dikonsumsi.

Total padatan terlarut biasanya digunakan untuk mengetahui jumlah gula yang terkandung pada bahan, dalam hal ini, gula yang dimaksudkan adalah laktosa karena laktosa merupakan gula yang paling dominan terdapat pada susu (Ningsih dan Bintoro, 2018). Hal tersebut sesuai dengan pendapat Sintasari et al. (2014) yang menyatakan bahwa total padatan terlarut dapat digunakan untuk mengetahui sisasisa gula seperti laktosa dari hasil perombakan selama proses fermentasi kefir. Hal ini diperkuat oleh pendapat Maitimu et al. (2012) yang menyatakan bahwa laktosa merupakan karbohidrat utama yang terdapat pada susu. Nira lontar mengandung gula dimana dalam proses destilasi gula yang terkandung dalam nira Lontar akan ikut menguap pada proses penyulingan/destilasi menjadi produk sopi. Gula merupakan komponen gizi dalam produk yang juga dimanfaatkan oleh bakteri asam laktat dalam menghasilkan metabolit. Hal ini sesuai dengan pendapat Zakaria (2009), yang menyatakan bahwa penurunan laktosa dan peningkatan asam laktat pada kefir dihasilkan dari proses fermentasi oleh bakteri asam laktat dan khamir, dimana laktosa terdegradasi menjadi glukosa dan galaktosa yang pada akhirnya menjadi asam laktat.

\section{Nilai Organoleptik Warna}

Warna merupakan parameter organoleptik yang penting dalam suatu produk makanan atau minuman. Warna adalah parameter pertama yang menentukan tingkat penerimaan konsumen terhadap suatu produk. Parameter warna pada suatu produk dan sebagai parameter utama bagi kenampakan produk 
secara keseluruhan. Berdasarkan hasil penelitian, tidak terjadi interaksi antar perlakuan pada parameter organoleptik warna, namun perlakuan jenis nira campuran memberi hasil yang berbeda nyata $(60,72)$ dengan perlakuan lainnya. Pada perlakuan tinggi sok, hasil penelitian menunjukan bahwa perlakuan tinggi sok $200 \mathrm{~cm}$ hasil sidik ragam berbeda nyata dengan perlakuan shok $50 \mathrm{~cm}$ akan tetapi tidak berbeda nyata dengan perlakuan sok $100 \mathrm{~cm}$ dan $150 \mathrm{~cm}$ (Tabel.4). Hal ini berarti antara perlakuan jenis nira bunga lontar dan perlakuan tinggi sok dapat menghasilkan produk sopi dengan warna yang agak menguning.

Tabel 4. Pengaruh Modifikasi Media Penyulingan dan Jenis Bunga Lontar Terhadap Warna Table 4. The effect of modification of distillation media and palm flower type on color

\begin{tabular}{|c|c|c|c|c|c|}
\hline \multirow{2}{*}{$\begin{array}{c}\begin{array}{c}\text { Perlakuan } \\
\text { (treatment) }\end{array} \\
\begin{array}{c}\text { Jenis Nira } \\
\text { (roomie type) }\end{array} \\
\end{array}$} & \multicolumn{4}{|c|}{$\begin{array}{l}\text { Tinggi sok penyulingan (cm) } \\
\text { (high refining shock) }\end{array}$} & \multirow{2}{*}{$\begin{array}{c}\text { Rerata } \\
\text { (average) }\end{array}$} \\
\hline & 50 (S1) & $100(\mathrm{~S} 2)$ & 150 (S3) & 200 (S4) & \\
\hline Betina (N1) & 50,4 & 47,1 & 55,46 & 47,06 & $47,03 \mathrm{~b}$ \\
\hline Jantan (N2) & 42,03 & 50,86 & 34,76 & 60,46 & $50,00 \mathrm{~b}$ \\
\hline \multicolumn{6}{|l|}{ Campuran } \\
\hline (N3) & 53,76 & 53,76 & 62,13 & 73,23 & $60,72 \mathrm{a}$ \\
\hline
\end{tabular}

\begin{tabular}{lllll}
\hline Rerata & $48,73 \mathrm{~b}$ & $50,57 \mathrm{ab}$ & $50,78 \mathrm{ab}$ & $60,25 \mathrm{a}$
\end{tabular}

Keterangan (Remark): angka yang diikuti huruf sama menunjukan tidak berbeda nyata pada $\alpha=5 \%$ (mean value followed by same letter indicated not significantly different at $\alpha=5 \%$ )

\section{E. Nilai Organoleptik Aroma}

Aroma merupakan salah satu parameter dalam pengujian sifat mutu suatu produk makanan atau minuman dengan cara pengujian menggunakan indera penciuman. Aroma dapat diterima apabila produk yang dihasilkan memiliki aroma yang spesifik. Aroma dari produk biasanya akan berkurang selama penanganan, pengolahan, penyimpanan, dan dipengaruhi oleh bahan yang digunakan.
Hasil pengujian pada produk sopi untuk pameter aroma menunjukan tidak terjadi interaksi antar perlakuan. Hasil penelitian menunjukkan bahwa perlakuan jenis nira campuran memberi nilai yang beda nyata yaitu 63,26 dibandingkan jenis nira bunga betina dan nira bunga jantan. Perlakuan tinggi sok tidak memberi hasil yang berbeda nyata, namun hasil terbaik berdasarkan sidik ragam (Anova) yaitu terdapat pada sok dengan ketinggian $150 \mathrm{~cm}$ (Tabel.5). 
Tabel 5. Pengaruh modifikasi Media Penyulingan dan Jenis Bunga Lontar Terhadap Aroma Table 5. The effect of modification of distillation media and palm flower type on flavor

\begin{tabular}{|c|c|c|c|c|c|}
\hline \multirow{2}{*}{$\begin{array}{c}\begin{array}{c}\text { Perlakuan } \\
\text { (treatment) }\end{array} \\
\begin{array}{c}\text { Jenis Nira } \\
\text { (roomie type) }\end{array}\end{array}$} & \multicolumn{4}{|c|}{$\begin{array}{l}\text { Tinggi sok penyuligan (cm) } \\
\text { (high refinng shok) }\end{array}$} & \multirow{2}{*}{$\begin{array}{c}\text { Rerata } \\
\text { (average) }\end{array}$} \\
\hline & 50 (S1) & $100(\mathrm{~S} 2)$ & $150(\mathrm{S3})$ & 200 (S4) & \\
\hline Betina (N1) & 53,9 & 53,8 & 60,5 & 53,76 & $55,74 \mathrm{~b}$ \\
\hline Jantan (N2) & 53,8 & 59,8 & 57,16 & 53,8 & $56,14 \mathrm{~b}$ \\
\hline \multicolumn{6}{|l|}{ Campuran } \\
\hline (N3) & 58,8 & 63,83 & 64,93 & 65,5 & $63,26 \mathrm{a}$ \\
\hline Rerata & 55,83 a & $59,14 \mathrm{a}$ & $60,86 \mathrm{a}$ & $57,68 \mathrm{a}$ & \\
\hline
\end{tabular}

Keterangan (Remark): angka yang diikuti huruf sama menunjukan tidak berbeda nyata pada $\alpha=5 \%$ (mean value followed by same letter indicated not significantly different at $\alpha=5 \%$ )

Aroma merupakan sifat mutu yang sangat cepat memberikan kesan bagi konsumen, karena aroma merupakan faktor yang sangat berpengaruh pada daya terima konsumen terhadap suatu produk. Berdasarkan hasil penelitian produk sopi, indikator aroma dari responden memberikan penilaian bahwa aroma dari produk sopi yang dihasilkan yaitu netral dengan kisaran nilai secara kuantitatif 40-60.

\section{F. Nilai Organoleptik Rasa}

Rasa merupakan faktor yang dapat memengaruhi penerimaan konsumen terhadap produk olahan pangan. Selain faktor tekstur, aroma, dan warna, seringkali rasa lebih dominan dipertimbangkan oleh konsumen dibandingkan sifat mutu lainnya. Hasil analisis parameter rasa produk sopi menunjukkan tidak terjadi interaksi antar perlakuan (Tabel 6). Perlakuan campuran bunga lontar memberikan hasil uji yang berbeda sangat nyata yaitu 64,14, dibanding perlakuan jenis nira bunga betina dan nira bunga jantan. Perlakuan tinggi sok dari hasil sidik ragam tidak memiliki hasil yang berbeda nyata antara setiap perlakuan.

Tabel 6. Pengaruh Modifikasi Media Penyulingan dan Jenis Bunga Lontar Terhadap Rasa Table 6. The effect of modification of distillation media and palm flower type on taste

\begin{tabular}{|c|c|c|c|c|c|}
\hline \multirow{2}{*}{$\begin{array}{c}\begin{array}{c}\text { Perlakuan } \\
\text { (treatment) }\end{array} \\
\begin{array}{c}\text { Jenis Nira } \\
\text { (roomie type) }\end{array} \\
\end{array}$} & \multicolumn{4}{|c|}{$\begin{array}{l}\text { Tinggi sok penyulingan (cm) } \\
\text { (high refining shock) }\end{array}$} & \multirow{2}{*}{$\begin{array}{c}\text { Rerata } \\
\text { (average) }\end{array}$} \\
\hline & 50 (S1) & $100(\mathrm{~S} 2)$ & $150(\mathrm{S3})$ & 200 (S4) & \\
\hline Betina (N1) & 48,73 & 53,8 & 60,5 & 53,76 & $54,20 \mathrm{~b}$ \\
\hline Jantan (N2) & 53,76 & 60,06 & 57,13 & 57,13 & $57,02 \mathrm{~b}$ \\
\hline Campuran (N3) & 57,1 & 67,16 & 64,93 & 67,36 & 64,14 a \\
\hline Rerata & $53,20 \mathrm{a}$ & $60,34 \mathrm{a}$ & $60,86 \mathrm{a}$ & $59,42 \mathrm{a}$ & $(-)$ \\
\hline
\end{tabular}

Keterangan (Remark): angka yang diikuti huruf sama menunjukan tidak berbeda nyata pada $\alpha=5 \%$ (mean value followed by same letter indicated not significantly different at $\alpha=5 \%$ ) 
Rasa suatu produk dipengaruhi oleh beberapa faktor yaitu penggunaan bahan dasar, senyawa kimia, suhu dan interaksi dengan komponen lain, (Winarno, 2004). Rasa juga nilainya sangat relatif, meskipun rasa dijadikan standar dalam penelitian mutu bahan makanan atau minuman. Berdasarkan hasil penelitian, dari 15 responden memberikan penilaian bahwa produk sopi yang dihasilkan. memiliki rasa yang disukai responden dengan nilai range 60-80. Hal ini menunjukkan bahwa antara perlakuan jenis nira lontar dan tinggi sok dapat menghasilkan rasa sopi yang disukai.

\section{KESIMPULAN}

Berdasarkan hasil penelitian menunjukkan bahwa perlakuan tinggi sok penyulingan dan jenis nira bunga lontar tidak terjadi interaksi antar perlakuan. Perlakuan jenis nira lontar memberikan pengaruh yang signifikan terhadap parameter kadar alkohol, $\mathrm{pH}$, total padatan terlarut, serta mutu organoleptik warna, aroma dan rasa. Perlakuan tinggi sok hanya memberikan pengaruh pada parameter kadar alkohol, total padatan terlarut dan warna. Kombinasi perlakuan tinggi sok $200 \mathrm{~cm}$ dan jenis bunga campuran yang menghasilkan kualitas paling produk sopi paling baik, dengan kadar alkohol 38,55\% dan mendekati nilai kadar alkohol untuk golongan $\mathrm{C}$ dimana sopi termasuk golongan $\mathrm{C}$. Oleh sebab itu, penyulingan nira lontar sebaiknya menggunakan tinggi sok 200 $\mathrm{cm}$ jenis nira campuran untuk menghasilkan kualitas produk sopi yang lebih baik.

Penelitian lanjutan yang dapat dipertimbangkan adalah penelitian media penyimpanan produk sopi yang dapat mempertahankan kualitas produk sopi, khususnya kadar alkohol. Selain itu diperlukan juga penelitian tentang mikroba yang terkandung dalam nira lontar yang dapat menghasilkan alkohol.

\section{DAFTAR PUSTAKA}

Arintawati,M. (2006). Mengenal minuman beralkohol.

https://www.republika.co.id/berita/2123

3/Mengenal_Minuman_Beralkohol

Diakses tanggal 06 April 2020.

Aryasa, I. W. T., Artini, N. P. R., Vidika A., D. P. R., \& Hendrayana, I. M. D. (2020). Kadar Alkohol Pada Minuman Tuak Desa Sanda Kecamatan Pupuan Kabupaten Tabanan Bali Menggunakan Metode Kromatografi Gas. Jurnal Ilmiah Medicamento, 5(1), 33-38.

Asosiasi Kefir Susu Indonesia. (2016). Pedoman Pembuatan dan Pemanfaatan Kefir. Rumah Kefir Bandung, Bandung

BPOM.(2014) Menilik Regulasi Minuman Beralkohol di Indonesia..BPOM RI, Jakarta.

Datta, F.U., \& Detha, A. (2016). Aktivitas Antimikroba Sopi Terhadap Bakteri Patogen Staphylococcus aureus. Prosiding Seminar Nasional Fakultas Kedokteran Hewan Ke-3, hal 68-72.

Detha, A., \& Datta, F.U. (2015). Aktivitas Antimikroba Sopi Terhadap Bakteri Patogen Salmonella typhimurium dan Salmonella enteritidis. Jurnal Kajian Veteriner 3: 56-61.

Detha, A., \& Datta, F.U. (2016a). Disinfektan Alternatif dari Bahan Alami. http://blog.undana.ac.id/jsmallfib_top/re pository/Annytha IR Detha/Karya Ilmiah/Bukti Lampiran 1_Penelitian_Buku.pdf.Diakses 20 Juni 2021. 
Detha, A., \& Datta, F.U. (2016b). Antimicrobial Activity of Traditional Wine (Sopi and Moke) against Salmonella sp and E. coli. Journal of Advanced Veterinary and Animal Research 3(3): 282-285.

Detha, A., \& Datta, F.U. (2016c). Skrining Fitokimia Minuman Tradisional Moke dan Sopi sebagai Kandidat Antimikroba. Jurnal Kajian Veteriner 4(1): 12-1.

Hidayanti, N. (2012). Artikel Pemanfaatan Pohon Aren. https://www.niahidayati.net/manfaatpohon-aren.html. Diakses 20 Juni 2020.

Kristanto.(2011). Sumber Daya Alam Dengan Kegiatan Ekonomi.Repositori UIN Syarif Hidayatullah, Jakarta.

Lempang, M. (2007). Fermentasi Nira Lontar Untuk Produk Nata. Jurnal Penelitian Hasil Hutan 25 (2): 147 - 157.

Li, D. E. (2013). Industrialisasi Sopi Di NTT Yang Berkelanjutan (Towards the Sustainability of NTT Sopi).IRGSC Policy Brief. 003, 1-8.

Maitimu, C.V., A.M. Legowo, \& A.N. AlBaarri. (2012). Parameter kadar lemak dan kadar laktosa susu pasteurisasi dengan penambahan ekstrak daun aileru (Wrightia calycina) selama penyimpanan. Ekosains 1(1): 28-34.

Mantut, H. P., Mauboy, R. S., \& Boro, T. L. (2019). Kajian tentang lama fermentasi nira lontar (Borassus flabeliffer L.) terhadap kelimpahan dan karakterisasi morfologi mikroba. Seminar Nasional Sains Dan Teknik FST UNDANA (Sainstek-IV), 79-86.

Manus, $\quad$ K (2017). Perbedaan Media Penyulingan Terhadap Kwalitas Sopi Timor. (Skripsi) Agroteknologi Fakultas
Pertanian. Universitas Timor. Kefamenanu.

Mardiyah, S. (2017). Pengaruh Lama Pemanasan Terhadap Kadar Alkohol Pada Nira Siwalan (Borassus flabellifer). The Journal of Muhammadiyah Medical Laboratory Technologist, 1(1), 9. https://doi.org/10.30651/jmlt.v1i1.977.

Naiola, E. (2008). Amylolitic microbes of nira and laru from Timor Island, East Nusa Tenggara. Biodiversitas, Journal of Biological Diversity, 9(3), 165-168. https://doi.org/10.13057/biodiv/d09030 2.

Ningsih, D. R., \& Bintoro, V. P. (2018). Analisis Total Padatan Terlarut, Kadar Alkohol, Nilai pH dan Total Asam pada Kefir Optima dengan Penambahan High Fructose Syrup (HFS). Jurnal Teknologi Pangan, 2(2), 84-89.

Nurtama, B. \& I. Naomi. (2010). Paket Industri Pembuatan Buah Lontar (Borassus flabellifer Linn.) Olahan. Buletin Teknik dan Industri Pangan, 1996; VII (2): 9599.

Parlindungan, T. (2010). Potensi dan Kebijakan Pengembangan Lontar Untuk Menambah Pendapatan Penduduk. Jurnal analisi kebijakan kehutanan. Vol 7.

Rahman. (2007). Teknologi Fermentasi. IPB. Bogor: Penerbit Arcan.

Rahmansyah, M. (2001). Perspektif Nira Lontar (Borassus flabellifer) Nusa Tenggara Timur. Alam Kita 10 (1): 15 - 23.

Rena, A. (2012). Pemanfaatan kulit buah siwalan (Borassus flabellifer 1.) sebagai bahan dasar pembuatan furfural. UNESA Journal of Chemistry Vol. 1, No. 2. 
Richana, N. (2011). Bioetanol : Bahan Baku, Teknologi Produksi dan Pengendalian mutu. Penerbit Nuansa. Bandung.

Sintasari, R.A., J. Kusnadi, \& D.W. Ningtyas. (2014). Pengaruh penambahan konsentrasi susu skim dan sukrosa terhadap karakteristik minuman probiotik sari beras merah.Jurnal Pangan dan Argoindustri 2(3): 65-75.

Subrimobdi, B. W. (2016). Studi Ekspermental Pengaruh Pengunaan Saccharomyces Cerevisiae Terhadap Tingkat Produksi Bioetaol Dengan Bahan Baku Nira Siwalan. (Skripsi) Program Studi Teknik Mesin. Fakultas Teknik. Universitas Muhammadiyah Yogyakarta.

Surroya, M.(2016). Pengaruh Suhu dan

\section{Lamanya Penyimpanan Terhadap} Kualitas Nira Siwalan dengan Penambahan Ekstrak Biji Kelengkeng. (Skripsi) Universitas Islam Negeri Maulana Malik Ibrahim Malang. Diakses pada tanggal 10 Mei 2019.

Wenur, F., \& Y. Waromi. (2017). Studi Pengolahan Bioetanol Tradisional Dari Nira Aren di Minahasa Selatan. Jurnal Teknologi Pertanian Volume 8, Nomor 2, Desember.

Winarno, F.G. 2004. Kimia Pangan dan Gizi. Gramedia Pustaka Utama. Jakarta.

Zakaria, Y. (2009). Pengaruh jenis susu dan persentase starter yang berbeda terhadap kualitas kefir. Agripet 9(1): 26- 30. 